\title{
PENDAMPINGAN PENYUSUNAN PERDES TENTANG PEMENUHAN AIR BERSIH BAGI MASYARAKAT DI DESA CAMPA KECAMATAN MADAPANGGA KABUPATEN BIMA
}

\author{
Jufrin $^{1}$, M.Firdaus ${ }^{2}$, Syahrul Ahmad ${ }^{3}$, Hajairin ${ }^{4}$, Anwar Sadat ${ }^{5}$, Suci Lestari ${ }^{6}$, Nurhayati ${ }^{7}$, Ahab \\ Mardianjah $^{8}$, M. Al Muarif ${ }^{9}$, Firman ${ }^{10}$, Urai Muhammad Esa ${ }^{11}$ dan Raizul Amin Loa Mena ${ }^{12}$ \\ Program Studi Ilmu Hukum; Sekolah Tinggi Ilmu Hukum Muhammadiyah Bima, Kota Bima-Indonesia \\ Email: hajairinbima91@gmail.com dan sucilestarii787@gmail.com
}

\begin{abstract}
Abstrak
Desa Campa Kecamatan Madapangga Kabupaten Bima, memiliki 3 sumber mata air yakni Oi Taba, Sori Nura Dan Lampuru, namun masyarakat di tempat tersebut mempunyai masalah yang cukup signifikan dalam memenuhi kebutuhan air secara umum, hal ini disebabkan oleh beberapa masalah. Kekurangan air bersih pada masyarakat menjadi masalah utama dalam pengabdian kepada masyarakat ini, hal ini disebabkan oleh kurangnya manajemen dari pemerintah desa dalam membuat saluran dan mengatur tentang pelaksanaan air bagi kebutuhan masayarakat di Desa Campa Kecamatan Madapangga Kabupaten Bima. Dengan demikian akan dilakukan pendampingan oleh Tim terhadap pemerintah desa, dalam menciptakan manajemen yang kepemimpinan yang dapat merangkul seluruh kebutuhan masyarakat, serta memenuhi kebutuhan mereka, termasuk pemenuhan kebutuhan air bersih bagi masyarakat yang sampai saat ini masih menjadi masalah yang cukup serius di Desa Campa Kecamatan Madapangga Kabupaten Bima. Beberapa permasalahan mitra adalah pertama Masalah utamanya adalah bukan tidak ada air dalam wilayah tersebut, hanya diperlukan pengaturan tentang bagaimana saluran air yang ada, sehingga masyarakat setempat, tidak mengeluhkan kekuarangan air, sebab masyarakat sangat sulit mendapatkan air bersih apabila tidak ada suatu tindakan atau kebijakan pemerintah desa setempat, selain itu air yang bersumber dari mata air yang ada harus semaksimal mungkin agar dapat dinikmati oleh seluruh masyarakat yang ada, sebagai bagian dari upaya pemenuhan air bersih bagi masyarakat di Desa Campa Kecamatan Madapangga Kabupaten Bima Kedua Belum ada Kebijakan yang memadai tentang perlindungan terhadap konservasi sumber mata air dan pemenuhan air bersih bagi masyarakat Desa Campa Kecamatan Madapangga Kabupaten Bima Ketiga Tidak adanya kesepahaman antara pemerintah desa dengan masyarakat setempat Keempat Desa Campa belum memilki Peraturan Desa tentang Pemenuhan Air Besih Keempat Masyarakat Setiap tahunnya selalu merebut air bersih dan masalah air menjadi masalah yang terus mengulang di Desa Campa Kecamatan Madapangga Kabupaten Bima.

Kata Kunci : Pendampingan; Penyusunan; Perdes; Air Bersih
\end{abstract}

\section{PENDAHULUAN}

Sebagai mitra dalam pengabdian kepada masyarakat ini adalah pemerintah desa, Badan permusyawaratan desa, sebagai bagian dari beberapa lembaga yang memiliki peran penting dalam mewujudkan air bersih bagi masyarakat di desa. Sebab jika manusia tidak dapat air, maka manusia akan kekurangan metabolism dalam tubuhnya. Perlindungan hukum terhadap sumber daya air ini penting sebagai aturan dan pedoman tingkahlaku manusia sebagaimana tujuan dari adanyahukum untuk mengatur tertib masyarakat. Per-kembangan hukum mengenai sumber daya airperlu di perbarui mengikuti perkembangan masya-rakat, sehingga terciptanya perlindungan hukumsumber daya air dapat memberikan dampak terhadap pelestarian air di Indonesia.

Desa Campa Kecamatan Madapangga Kabupaten Bima, memiliki 3 sumber mata air yakni Oi Taba, Sori Nura Dan Lampuru, namun

Ekonomi, Sosial, dan Budaya | 1371 
masyarakat di tempat tersebut mempunyai masalah yang cukup signifikan dalam memenuhi kebutuhan air secara umum, hal ini disebabkan oleh beberapa masalah. Padahal Air adalah kebutuhan pokok mahluk hidup termasuk di dalamnya manusia. Dalam melanjutkan kelangsungan kehidupan rumah tangga seharihari maupun kebutuhan proses industri sangat memerlukan ketersediaan air bersih yang memadai. Pada umumnya suatu daerah yang subur ditandai dengan debit air tanahnya yang tinggi, sebaliknya daerah yang kurang subur bahkan gersang debit air tanahnya terbatas. Air menduduki urutan prioritas persyaratan penting dalam mendukung laju proses perkembangan suatu daerah (Volentino Deo, 2013).

Kebutuhan air untuk kepentingan sosial maupun komersial semakin meningkat, di sisi lain cadangan air semakin berkurang apalagi pada saat musim kemarau, sehingga menimbulkan kecenderungan untuk tidak mematuhi ketentuan dan peraturan sesuai dengan kesepakatan bersama, antara lain adanya upaya memotong jalur air, merusak pipa air yang telah tersedia, sehingga dapat menimbulkan konflik bagi para pengguna. Upaya sistematis dan terpadu tersebut meliputi perencanaan, pemanfaatan, pengendalian, pemeliharaan, pengawasan, dan penegakan hukum sebagai upaya dalam Keberlangsungan perlindungan lingkungan hidup (Galih Puji Mulyono, 2019).

Berdasarkan analisis situasi dapat digambarkan permasalahan mitar sebagai berikut: Pertama Masalah utamanya adalah bukan tidak ada air dalam wilayah tersebut, hanya diperlukan pengaturan tentang bagaimana saluran air yang ada, sehingga masyarakat setempat, tidak mengeluhkan kekuarangan air, sebab masyarakat sangat sulit mendapatkan air bersih apabila tidak ada suatu tindakan atau kebijakan pemerintah desa setempat, selain itu air yang bersumber dari mata air yang ada harus semaksimal mungkin agar dapat dinikmati oleh seluruh masyarakat yang ada, sebagai bagian dari upaya pemenuhan air bersih bagi masyarakat di Desa Campa Kecamatan Madapangga Kabupaten Bima; Kedua Belum ada Kebijakan yang memadai tentang perlindungan terhadap konservasi sumber mata air dan pemenuhan air bersih bagi masyarakat Desa Campa Kecamatan Madapangga Kabupaten Bima; Ketiga Tidak adanya kesepahaman antara pemerintah desa dengan masyarakat setempat; Keempat Desa Campa belum memilki Peraturan Desa tentang Pemenuhan Air Besih dan Kelima Masyarakat Setiap tahunnya selalu merebut air bersih dan masalah air menjadi masalah yang terus mengulang di Desa Campa Kecamatan Madapangga Kabupaten Bima.

\section{METODE}

Kegiatan PKM ini akan dilaksanakan selama 2 (dua) bulan di tahun 2021 (Juli agustus) yang terbagi ke dalam 7 (tujuh) tahapan yaitu:

1. Tahap Persiapan

Tahap persiapan terdiri dari dua, persiapan pengusul dan persiapan lapangan. Tim pengusul mengadakan pertemuan antar anggota Tim untuk menyamakan persepsi dan menentukan urutan kegiatan yang akan dilaksanakan. Sedangkan persiapan lapangan dilakukan melalui studi kelayakan terhadap daerah yang akan dijadikan sebagai mitra, baik dilakukan secara formal maupun informal. Bila sudah ditemukan mitra yang ingin dikembangkan, pengusul harus mencoba menerobos jalur formal untuk mendapat perizinan dari pihak terkait. Di samping itu, pengusul juga harus menjalin kontak dengan tokoh-tokoh informal agar hubungan dengan masyarakat dapat terjalin dengan baik.

2. Tahap pengkajian, yaitu melakukan identifikasi masalah atau kebutuhan yang diekspresikan dan sumber daya yang dimiliki mitra. Mitra dilibatkan secara aktif agar permasalahan yang keluar adalah dari 
pandangan mereka sendiri, dan pengusul memfasilitasi mitra untuk menyusun prioritas dari permasalahan yang mereka sampaikan. Hasil pengkajian ini akan ditindaklanjuti pada tahap berikutnya, yaitu tahap perencanaan Tahap pengkajian dilakukan dengan Focus Group Discution (FGD).

3. Tahap perencanaan alternatif kegiatan

Pada tahap ini pengusul secara partisipatif mencoba melibatkan mitra untuk berpikir tentang masalah yang mereka hadapi, bagaimana cara mengatasinya serta memikirkan beberapa alternative program dan kegiatan yang dapat dilakukan.

4. Tahap formulasi rencana aksi

Pada tahap ini pengusul membantu mitra untuk merumuskan dan menentukan program dan kegiatan apa yang akan mereka lakukan guna mengadaptasi permasalahan yang ada.

5. Tahap inplementasi kegiatan

Tahap pelaksanaan terdiri dari:

- Rapat Persiapan;

- Pengumpulan bahan;

- Studi lapangan;

- Penyusunan Konsep Rancangan Perdes;

- Rapat Pembahasan Konsep Rancangan Perdes

- Perumusan Rancangan Perdes

- Rapat Konsultasi dengan Masyarakat, Camat dan Pemkab Bima;

- Penyusunan naskah final Rancangan Perdes

6. Tahap evaluasi

7. Tahap terminasi

\section{HASIL DAN PEMBAHASAN}

Diperlukan suatu pengetahuan yang dapat menunjang adanya pemahaman bahwa Semua aturan/kebijakan yang dibuat memang harus datang dari masyarakat sendiri, dari kebutuhan mereka untuk menjawab persoalanpersoalan yang ada selama ini di desa sehingga mereka sendiri yang dapat menentukan sangsinya seperti apa. Dengan proses seperti ini, diharapkan penegakan aturan di desa lebih tertib yang berdampak pada kesejahteraan bersama. Dalam pelaksanaan kegiatan ini juga diharapkan adanya Rancangan peraturan desa, tentang pemenuhan air bersih bagi masyarakat, sehingga dalam pendampinganya secara bersama-sama dengan pemerintah Desa Campa Kecamatan Madapangga Kabupaten Bima.

Mewujudkan peraturan desa tentang pemenuhan air bersih adalah gambaran ilmu pengetahuan (iptek) yang akan di implementasikan, seperti memberikan pemahaman tentang bagaimana menyusun naskah akademik sebelum menyusur Perdes, selain itu juga menjelaskan tentang subtansi yang harus di penuhi dalam penyusuna Perdes, kemudian menjelaskan tentang landasan hukum dan pendampingan penyusunan perdes. Dalam merencanakan penyusunan perdes tentang perlindungan mata air pemerintah dalam mengambil kebijakan harus berdasarkan peraturan perundangan-undangan yang ada. Sebagai kebijakan umum pemerintah desa harus berjalan berdasarkan Undang-Undang Nomor 6 Tahun 2014 tentang Desa, Peraturan Pemerintah Nomor 43 Tahun 2014 jo Peraturan Pemerintah Nomor 76 Tahun 2015 tentang Peraturan Pelaksana dalam Undang-Undang Nomor 6 Tahun 2014 tentang Desa. Sementara sebagai petunjuk teknis harus berdasarkan pada UndangUndang nomor 12 tahun 2011 tentang pembentukan peraturan perundang-Undangan, Permendagri Nomor 11 Tahun 2014 tentang Pedoman Teknis Peraturan di Desa, serta Peraturan bupati Bima nomor 35 tahun 2020 tentang pedoman teknis pembentukan produk Hukum Desa.

Tahapan pelaksanaan solusi yang ditawarkan untuk mengatasi permasalahan mitra dalam Pemenuhan kebutuhan air bersih di Desa Campa Kecamatan Madapangga Kabupaten Bima. Kekurangan air bersih pada masyarakat menjadi masalah utama dalam pengabdian kepada masyarakat ini, hal ini disebabkan oleh kurangnya manajemen dari pemerintah desa dalam membuat saluran dan mengatur tentang 
pelaksanaan air bagi kebutuhan masayarakat di Desa Campa Kecamatan Madapangga Kabupaten Bima. Dengan demikian akan dilakukan pendampingan oleh Tim terhadap pemerintah desa, dalam menciptakan manajemen yang kepemimpinan yang dapat merangkul seluruh kebutuhan masyarakat, serta memenuhi kebutuhan mereka, termasuk pemenuhan kebutuhan air bersih bagi masyarakat yang sampai saat ini masih menjadi masalah yang cukup serius di Desa Campa Kecamatan Madapangga Kabupaten Bima.

Dalam melindungi sumber mata air tersebut dibutuhkan konservasi, konservasi merupakan alokasi sumber daya antar waktu yang optimal secara sosial. Secara umum konservasi merupakan pengelolaan sumberdaya secara bijaksana untuk menjamin kesinambungan persediaannya dengan tetap memelihara dan meningkatkan kualitas nilai. Upaya konservasi akan berjalan dengan baik jika ada kerjasama pemerintah dan masyarakat (Sudarmadji, dkk, 2016). Penerapan konservasi tanah dan air merupakan strategi utama dalam upaya pelestarian dan pemanfaatan lingkungan hidup serta sumberdaya alam. Berbagai upaya yang dilakukan untuk meningkatkan stabilitas tanah sehingga suatu lahan mampu mendukung aktivitas makhluk hidup dapat diterapkan dengan konservasi tanah baik secara vegetatif, mekanik, dan kimia (Suripin, 2004).

Permasalahan Dalam Bidang Kebijakan Penyusunan Perdes Pemenuhan Air Bersih, Secara umum, saluran air yang di desa Campa masih dilakukan dengan sederhana. Ada beberapa faktor yang perlu diperhatikan dalam memenuhi kebutuhan air bersih bagi masyarakat secara menyeluruh, yang juga dapat menentukan keberhasilan pemerintah desa itu sendiri. Faktorfaktor tersebut adalah: Pemilihan lokasi penampungan air harus di tempat strategis. Hal ini perlu dilakukan karena ada perlakukan yang berbeda dari masyarakat, lokasi penampungan air tersebut juga dapat mempengaruhi saluran air bagi masyarakat Desa Campa Kecamatan Madapangga Kabupaten Bima; Pemilihan Pipa dan tempat saluran air menjadi sangat penting untuk di perhatikan, hal ini tentu dilakukan berdasarkan berbagai pertimbangan, seperti pemotongan pipa, pipa yang mudah ditutup sesuatu, hingga menghambat saluran air yang ada, bahkan jenis pipa yang digunakan dapat juga di tuangkan dalam peraturan desa tersebut, asas-asas yang utama adalah adanya kesamaan pendapat dan visi tentang bagaimana masyarakat dapat memenuhi kebutuhan air maupun air bersih.

Keseluruhan aspek-aspek tersebut menjadi bahan untuk menyusun suatu peraturan desa, yang mengatur secara detail tentang saluran air dan pemenuhan air bersih di Desa Campa Kecamatan Madapangga Kabupaten Bima, hal ini penting dilakukan untuk memastikan adanya hak hukum bagi masyarakat untuk mendapatkan air bersih tersebut, sehingga masyarakat tidak lagi memilki kesulitan untuk mendapatkan air bersih, apalagi di musim kemarau seperti sekarang ini.

Beberapa tahapan dalam pendampingan penyusunan peraturan desa campa tentang pemenuhan air bersih

\section{Tahapan Persiapan}

Tahap persiapan terdiri dari dua, persiapan pengusul dan persiapan lapangan. Tim pengusul mengadakan pertemuan antar anggota Tim untuk menyamakan persepsi dan menentukan urutan kegiatan yang akan dilaksanakan. Sedangkan persiapan lapangan dilakukan melalui studi kelayakan terhadap daerah yang akan dijadikan sebagai mitra, baik dilakukan secara formal maupun informal. Bila sudah ditemukan mitra yang ingin dikembangkan 


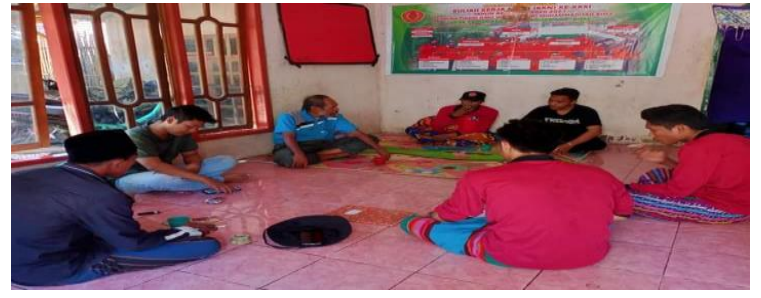

Gambar 1: Saat melakukan pertemuan dengan TIM

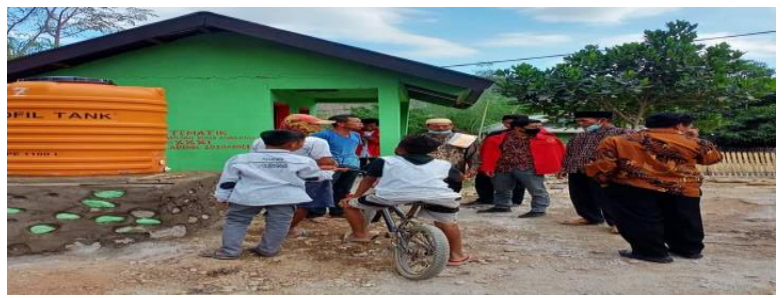

Gambar 2: Survei Penampung Air Bersih

2. Tahap pengkajian, yaitu melakukan identifikasi masalah atau kebutuhan yang diekspresikan dan sumber daya yang dimiliki mitra. Mitra dilibatkan secara aktif agar permasalahan yang keluar adalah dari pandangan mereka sendiri, dan pengusul memfasilitasi mitra untuk menyusun prioritas dari permasalahan yang mereka sampaikan. Hasil pengkajian ini akan ditindaklanjuti pada tahap berikutnya, yaitu tahap perencanaan Tahap pengkajian dilakukan dengan Focus Group Discution (FGD).

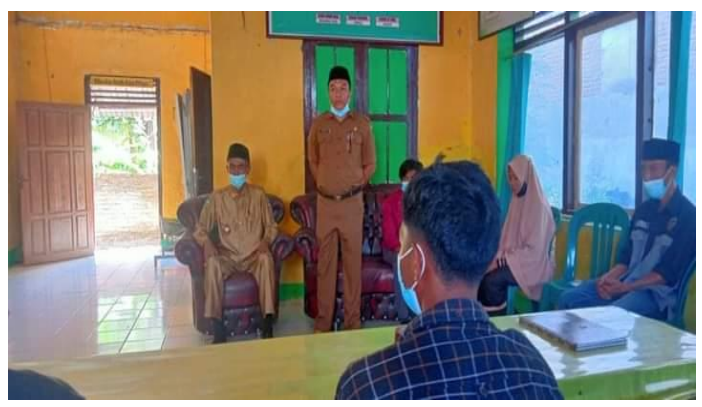

Gambar 3: Pendampingan Penyusunan Prioritas Masalah

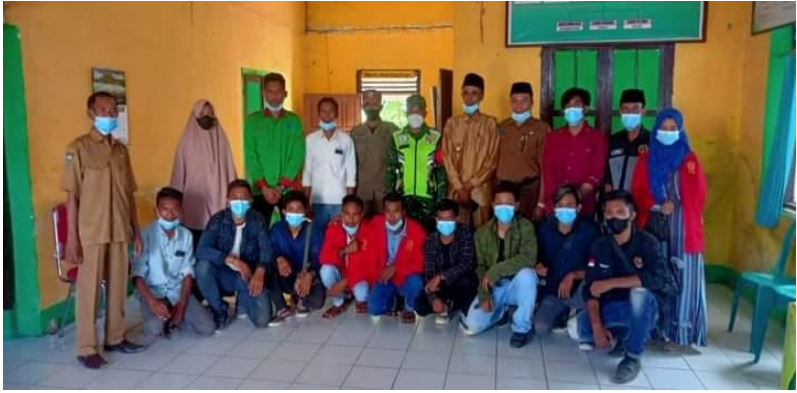

Gambar 4: Saat Melaksanakan FGD

3. Tahap perencanaan alternatif kegiatan

Pada tahap ini pengusul secara partisipatif mencoba melibatkan mitra untuk berpikir tentang masalah yang mereka hadapi, bagaimana cara mengatasinya serta memikirkan beberapa alternative program dan kegiatan yang dapat dilakukan.

4. Tahap formulasi rencana aksi

Pada tahap ini pengusul membantu mitra untuk merumuskan dan menentukan program dan kegiatan apa yang akan mereka lakukan guna mengadaptasi permasalahan yang ada.

5. Tahap inplementasi kegiatan

Tahap pelaksanaan terdiri dari:

- Rapat Persiapan;

- Pengumpulan bahan;

- Studi lapangan;

- Penyusunan Konsep Rancangan Perdes;

- Rapat Pembahasan Konsep Rancangan

Perdes

- Perumusan Rancangan Perdes

- Rapat Konsultasi dengan Masyarakat, Camat dan Pemkab Bima;

- Penyusunan naskah final Rancangan Perdes

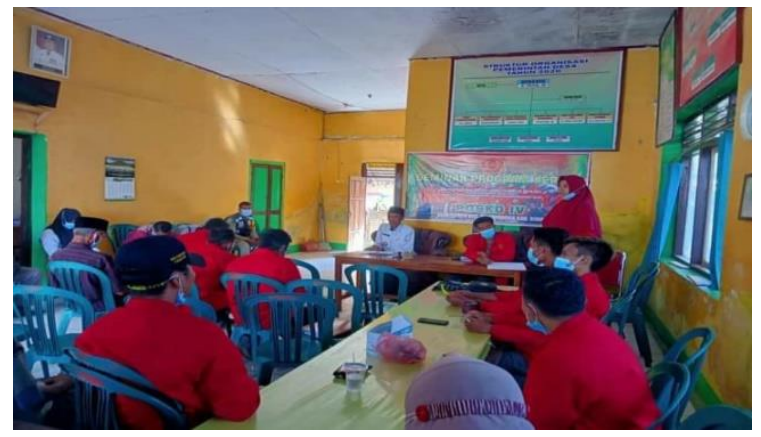

Gambar 5: Saat Rapat

Ekonomi, Sosial, dan Budaya 1375 


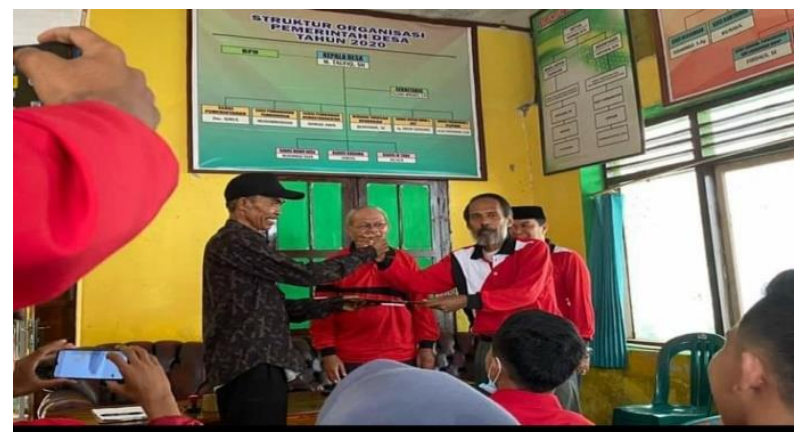

Gambar 6: Rapat Pembahasan Rancangan Perdes

\section{KESIMPULAN}

Berdasarkan hasil dan pembahasan diatas dapat disimpulkan bahwa pertama diperlukan menyusun suatu naskah akademik sebagai landasan penyusunan rancangan peraturan desa tentang pemenuhan air bersih di Desa Campa Kecamatan Madapangga Kabupaten Bima. Kedua Draf Naskah Akademik Tentang Pemenuhan Air Bersih Melakukan Komunikasi dengan Bebagai Pihak untuk menentukan pembuatan Bak Penampung Air Besih, agar air dapat mengalir kepada seluruh masyarakat. Luaran adalah Pembuatan Bak Air. Ketiga Pendampingan Penyusunan Rancanagan peraturan desa, sampai tersusunya draf Perda Tentang Pemenuhan Air Bersih.

\section{UCAPAN TERIMA KASIH}

Dalam melaksanakan pendampingan penyusunan peraturan desa tentang pemenuhan air bersih, saya mengucapkan terima kasih kepada lembaga STIH Muhammadiyah Bima, Pemerintah Desa Campa, Masyarakat, Tokoh pemudan dan tokoh adat yang ada di Desa Campa Kccamatan Madapangga Kabupaten Bima

\section{REFERENSI}

1. Galih Puji Mulyono (2019) Perlindungan Hukum Terhadap Tata Penglolaan Air di Indonesia, Jurnal Cakrawala Hukum, Volume 10 No. 1 Juni 2019

2. Volentino Deo, (2013), "Kajian Pengawasan Pemanfaatan Sumberdaya Air Tanah di Kawasan Industri”, Jurnal
Manusia Dan Lingkungan, Vol. 1/No. 3/Desember/2013, Lardem, Hal 266

3. Sudarmadji, dkk, (2016), "Pengelolaan Mata Air Untuk Penyediaan Air Rumah Tangga Berkelanjutan Di Lereng Selatan Gunung Api Merapi”, Jurnal Manusia Dan Lingkungan, Vol. 23/No. 1/Maret/2016, PSLH Universitas Gadjah Mada, Hal 103

4. Suripin, (2004), Pelestarian Sumber Daya Tanah dan Air, Andi, Yogyakarta, Hal 72

5. Undang-Undang Nomor 6 Tahun 2014 tentang Desa

6. Peraturan Pemerintah Nomor 43 Tahun 2014 jo Peraturan Pemerintah Nomor 76 Tahun 2015 tentang Peraturan Pelaksana dalam Undang-Undang Nomor 6 Tahun 2014 tentang Desa

7. Undang-Undang nomor 12 tahun 2011 tentang pembentukan peraturan perundangUndangan;

8. Permendagri Nomor 11 Tahun 2014 tentang Pedoman Teknis Peraturan di Desa

9. Peraturan bupati Bima nomor 35 tahun 2020 tentang pedoman teknis pembentukan produk Hukum Desa 